\title{
Molecular Characterization of High-Level Aminoglycoside Resistance among Enterococcus Species
}

\author{
Harish Manoharan ${ }^{1}$ Aishwarya K.V. Lalitha ${ }^{1}$ Shanthi Mariappan ${ }^{1}$ Uma Sekar ${ }^{1}$ \\ Geetha P. Venkataramana ${ }^{1}$ \\ ${ }^{1}$ Department of Microbiology, Sri Ramachandra Institute for Higher \\ Education and Research, Chennai, Tamil Nadu, India \\ J Lab Physicians 2022;14:290-294. \\ Address for correspondence Harish Manoharan, MBBS, MD, FIID, \\ Department of Microbiology, Sri Ramachandra Institute for Higher \\ Education and Research, Porur, Chennai, 600116, Tamil Nadu, India \\ (e-mail: manoharan.harish@gmail.com).
}

\begin{abstract}
Keywords

- AMEs

- Enterococcus species

- high-level aminoglycoside resistance

- encoding genes
\end{abstract}

Background Enterococci are nosocomial pathogen. They can develop high-level resistance to aminoglycoside by producing aminoglycoside modifying enzymes (AMEs). In enterococci, high level resistance to aminoglycosides is mediated by acquisition of plasmid mediated genes encoding for aminoglycoside modifying enzymes (AMEs). High level gentamicin resistance (MIC $\geq 500 \mu \mathrm{g} / \mathrm{mL}$ ) is predominantly mediated by aac $\left(6^{\prime}\right)$-le-aph $\left(2^{\prime \prime}\right)$ la, encoding the bifunctional aminoglycoside modifying enzyme $A A C\left(6^{\prime}\right)-A P H\left(2^{\prime \prime}\right)$. This enzyme eliminates the synergistic activity of gentamicin when combined with a cell wall active agent. Other AME genes such as aph( (2")-Ib, aph(2")-Ic, aph(2")-Id and ant(4')-1a have also been detected in enterococci.

Objective This study was carried out to determine the diverse prevalence of AME and their pattern of occurrence in the clinical isolates of Enterococci.

Materials and Methods A total number of 150 clinical isolates were included in this study. Susceptibility to various antibiotics was determined by disc diffusion. Minimum Inhibitory Concentration (MIC) was ascertained by agar dilution method. Polymerase chain reaction was done to screen the following AMEs (aac(6')-le-aph(2")-la; $a p h\left(2^{\prime \prime}\right)-l b$; aph(2")-Ic; aph(2")-Id and aph(3')- Illa genes).

Results $51.3 \%$ of the study isolates exhibited high level gentamicin resistance. Polymerase chain reaction revealed that $a p h\left(3^{\prime}\right)-111 a$ is the most prevalent AME, followed by aac (6')-1e-aph(2")-1a. The combination of both the genes were detected in $44.1 \%$ of the study isolates. The rest of the AMEs and their combinations were not encountered in this study. $8.6 \%$ of the study isolates did not harbour any AME genes screened for, but was phenotypically resistant to gentamicin. In contrast 31.3\% anchored the AME genes but phenotypically appeared susceptible to gentamicin.

Conclusion This study indicates the high- level aminoglycoside resistance disseminated among Enterococci in our geographical region. It also emphasizes the detection of AMEs by PCR is mandatory because strains that appear susceptible by disc diffusion and/or MIC method may harbour one or more AMEs genes leading to therapeutic failure. published online February 23, 2022
DOI https://doi.org/

$10.1055 / \mathrm{s}-0042-1742423$. ISSN $0974-2727$.
(C) 2022. The Indian Association of Laboratory Physicians. All rights reserved.

This is an open access article published by Thieme under the terms of the Creative Commons Attribution-NonDerivative-NonCommercial-License, permitting copying and reproduction so long as the original work is given appropriate credit. Contents may not be used for commercial purposes, or adapted, remixed, transformed or built upon. (https://creativecommons.org/ licenses/by-nc-nd/4.0/)

Thieme Medical and Scientific Publishers Pvt. Ltd., A-12, 2nd Floor, Sector 2, Noida-201301 UP, India 


\section{Introduction}

Enterococci have emerged as an important multidrug-resistant nosocomial pathogen causing health-care-associated infections ranging from urinary tract infection, to surgical site infection, prosthetic valve endocarditis, and sepsis. They are highly resilient and versatile, which make them adaptive and survive in the health care environments. ${ }^{1}$

Two species Enterococcus faecalis and Enterococcus faecium cause the majority of enterococcal infections. They exhibit multidrug resistance by both intrinsic and extrinsic mechanisms. Intrinsically they are resistant to common antibiotics like cephalosporins, penicillinase-resistant penicillin, low-level aminoglycosides, clindamycin, sulfamethoxazole, and trimethoprim. Extrinsically they acquire resistance to high-level aminoglycoside, high-level ampicillin, and vancomycin either through mutations or horizontal transfer of resistant genes. ${ }^{1}$

Enterococci can develop resistance to aminoglycoside by two different mechanisms, one is the low-level resistance which is due to reduced cell wall permeability and this type can be overcome by using a combination of aminoglycoside and cell-wall-acting agents. Another mechanism is the highlevel resistance (HLR) which is due to the production of aminoglycoside-modifying enzymes (AMEs). This enzyme in enterococci negates the synergistic activity of aminoglycoside when it is being combined with a cell-wall-acting agent. 2,3

Previously $a a c\left(6^{\prime}\right)-I e-a p h\left(2^{\prime \prime}\right)-I a$ was the only gene found to be associated with high level gentamicin resistance (HLGR). But in recent years three new AME genes that mediate HLGR in enterococci have been detected, namely $\operatorname{aph}\left(2^{\prime \prime}\right)-I b, \operatorname{aph}\left(2^{\prime \prime}\right)-I c$, and $\operatorname{aph}\left(2^{\prime \prime}\right)-I d$. Resistance to other aminoglycosides like high level streptomycin and high level kanamycin are usually mediated by aph(3')-IIIa gene but not to gentamicin. Ant(4')-Ia gene is also usually associated with high level Aminoglycoside resistance (HLAR). ${ }^{2,4-9}$

Studies on prevalence of these resistance genes are limited. The purpose of this study is to determine the rate of HLARs and their genetic mechanism in clinical isolates of enterococci. Also, to screen for other common genes that encode for HLAR.

\section{Materials and Methods}

\section{Study Setting}

This study was conducted in a 1,600-bedded university teaching hospital from August 2018 to February 2019. The study protocol was approved by the institutional ethics committee (REF: CSP-MED/18/AUG/45/113).

\section{Bacterial Strains}

The study included 150 clinically significant, consecutive, and nonrepetitive enterococcal isolates recovered from clinical specimens of hospitalized patients. The isolates were obtained from clinical specimens such as blood, pus, and urine. The organisms were identified up to species level either by conventional biochemical tests or by an automated method (Micro scan Walk Away 96, Gram-positive panels). Care was taken to differentiate commensals from pathogens for isolates obtained from nonsterile sites (urinary tract and wound swabs). The significance of the isolates was based on clinical history, presence of the organism in the Gram stain, presence of intracellular forms of the organism, and growth in culture with a significant colony count.

\section{Antimicrobial Susceptibility Testing}

Susceptibility to various classes of antibiotics was determined by the disc diffusion method in accordance with Clinical Laboratory Standard Institute (CLSI 2018) guidelines. The antibiotics tested were ampicillin $(10 \mu \mathrm{g})$, high-level gentamicin $(120 \mu \mathrm{g})$, erythromycin $(15 \mu \mathrm{g})$ (for isolates from exudates), vancomycin $(30 \mu \mathrm{g})$, linezolid $(30 \mu \mathrm{g})$, nitrofurantoin $(300 \mu \mathrm{g})$ (for urinary isolates), and ciprofloxacin $(5 \mu \mathrm{g})$ (for urinary isolates). The antimicrobial agents were procured from Himedia Laboratories (Mumbai, Maharashtra, India).

\section{Minimal Inhibitory Concentration}

The overnight bacterial culture was inoculated in a nutrient broth and incubated for 20 minutes. The turbidity was adjusted to 0.5 McFarland standard. An amount of $1 \mu \mathrm{L}$ of this inoculum containing $10 \mathrm{cfu} /$ spot was spotted on a nutrient agar plate containing gentamicin at a concentration of 500 $\mu \mathrm{g} / \mathrm{mL}$. Growth of organism in the media was indicative of HLGR.

\section{Template DNA Preparation}

A single bacterial colony was inoculated into Luria-Bertani broth (Himedia Laboratories, Mumbai, Maharashtra, India) and incubated overnight at $37^{\circ} \mathrm{C}$, and it was then centrifuged at $10,000 \mathrm{rpm}$ for 10 minutes. The pellet was re-suspended in $250 \mu \mathrm{L}$ of Millipore water, boiled at $100^{\circ} \mathrm{C}$ for 10 minutes, and cooled and centrifuged at $10,000 \mathrm{rpm}$ for 10 minutes. The supernatant served as the template DNA.

\section{Polymerase Chain Reaction}

Two sets of multiplex and one simplex polymerase chain reactions (PCRs) were performed using the previously described primers and conditions for all the study isolates. The multiplex primers used for different sets of genes, their annealing temperature, and the amplicon size are listed in - Table 1.

Each reaction volume contained $2 \mu \mathrm{L}$ of the DNA template added to the master mix which includes $10 \mathrm{pmol}$ of the forward and reverse primers (Sigma-Aldrich, Missouri, United States), 10 Mm dNTPs (Takara, Shiga, Japan), 5 U taq polymerase (Takara, Shiga, Japan), and 10X buffer with $\mathrm{MgCl}_{2}$ (Takara, Shiga, Japan).

Amplification reactions were performed under the following conditions: initial denaturation at $95^{\circ} \mathrm{C}$ for 5 minutes, followed by 32 cycles of denaturation at $95^{\circ} \mathrm{C}$ for 60 seconds, annealing at $58^{\circ} \mathrm{C}$ for 45 seconds, and elongation at $72^{\circ} \mathrm{C}$ for 60 seconds, repeated for 32 cycles and a final extension at $72^{\circ} \mathrm{C}$ for 5 minutes. The PCR product was then run on a $1.5 \%$ agarose gel for detection of the amplified fragment (-Fig. 1). 
Table 1 Genes and their sequences for aminoglycoside-modifying enzymes used in PCR

\begin{tabular}{|l|l|l|l|l|}
\hline Multiplex set & Gene & Primer sequence $\left(5^{\prime} \rightarrow 3^{\prime}\right)$ & $\begin{array}{l}\text { Amplicon size } \\
(\mathbf{b p})\end{array}$ & $\begin{array}{l}\text { Annealing temperature } \\
\left({ }^{\circ} \mathrm{C}\right)\end{array}$ \\
\hline 1 & $a a c\left(6^{\prime}\right)-l e-a p h\left(2^{\prime \prime}\right)-l a$ & $\begin{array}{l}\text { F-CAGGAATTTATCGAAAATGGTAGAAAAG } \\
\text { R-CACAATCGACTAAAGAGTACCAATC }\end{array}$ & 369 & 58 \\
\hline & $a p h\left(3^{\prime}\right)-I l l a$ & $\begin{array}{l}\text { F-GGCTAAAATGAGAATATCACCGG } \\
\text { R-CTTTAAAAAATCATACAGCTCGCG }\end{array}$ & 523 & 58 \\
\hline 2 & $a p h\left(2^{\prime \prime}\right)-l b$ & $\begin{array}{l}\text { F-CTTGGACGCTGAGATATATGAGCAC } \\
\text { R-GTTTGTAGCAATTCAGAAACACCCTT }\end{array}$ & 867 & 58 \\
\hline & $a p h\left(2^{\prime \prime}\right)-l c$ & $\begin{array}{l}\text { F-CCACAATGATAATGACTCAGTTCCC } \\
\text { R-CCACAGCTTCCGATAGCAAGAG }\end{array}$ & 444 & 58 \\
\hline Simplex & $a p h\left(2^{\prime \prime}\right)-I d$ & $\begin{array}{l}\text { F-GTGGTTTTTACAGGAATGCCATC } \\
\text { R-CCCTCTTCATACCAATCCATATAACC }\end{array}$ & 641 & 58 \\
\hline
\end{tabular}

Abbreviation: PCR, polymerase chain reaction.

\section{Nucleotide Sequencing}

PCR-positives were purified and sequenced. Sequencing was performed using the BigDye 3.1 cycle sequencing kit in Sanger AB13730 XL DNA analyzing instrument (AgriGenome). The aligned sequences were then analyzed with the Bioedit sequence program. Similarity searches for the nucleotide sequences were performed with the BLAST program and sequences were submitted for the accession numbers (http://www.ncbi.nlm.nih.gov). These sequenced strains served as positive controls.

$\mathrm{T} 1 \mathrm{~T} 2$

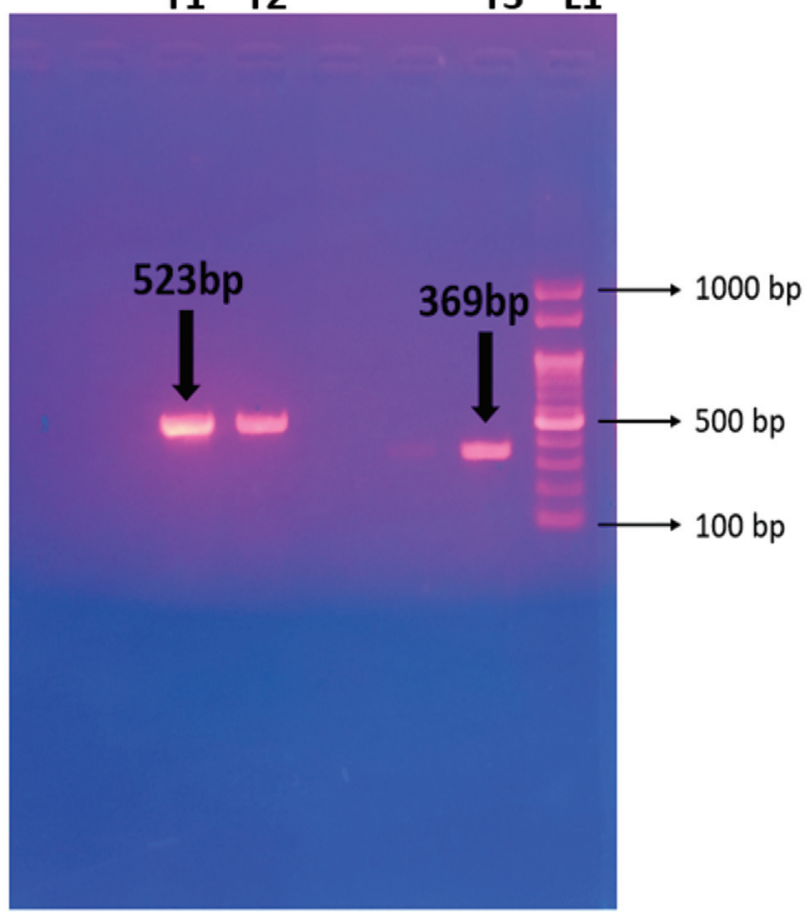

Fig. 1 Image of gel electrophoresis of PCR for detecting aminoglycoside modifying enzyme (AME) gene. Band at 523bp (T1\&T2) represents the presence of aph(3')-Illa gene and band at 369bp (T3) represents presence of aac $\left(6^{\prime}\right)$-le-aph $\left(2^{\prime \prime}\right)$-la gene. L1 is the $100 \mathrm{bp}$ ladder. PCR, polymerase chain reaction.

\section{Results}

Out of the 150 isolates, 130 (86.6\%) were E. faecalis and 20 (13.3\%) were E. faecium. They were obtained from exudates (pus and wound swabs) 95 (63.3\%), urine 52 (34.6\%), and blood 3 (2\%) (-Table 2).

By the Kirby-Bauer disc diffusion method, sensitivity percentages to antibiotics tested are as follows: ampicillin 75\% (113/150), high-level gentamicin 48.7\% (73/150), erythromycin for isolates from exudates 13\% (12/95), vancomycin 98\% (147/150), linezolid 100\% (150/150), nitrofurantoin 98\% (51/52), and ciprofloxacin 46\% (24/52).

Minimal inhibitory concentration (MIC) by the agar dilution method revealed high-level gentamicin $(>500 \mu \mathrm{g} / \mathrm{mL}$ ) resistance in 51.3\% (77/150) isolates (-Fig. 2).

PCR screening for AME genes revealed that 111 of the 150 isolates harbored one or more AME-encoding genes. This distribution is as follows: $11.3 \%(17 / 150)$ isolates harbored $\operatorname{aac}\left(6^{\prime}\right)-1 e-\operatorname{aph}\left(2^{\prime \prime}\right)-1 a$ gene alone, $18.6 \%(28 / 150)$ isolates carried $a p h\left(3^{\prime}\right)-111 a$ gene alone, and $44.1 \%$ (66/150) isolates co-harbored both the above genes. The other AME genes were not detected in this study ( - Table $\mathbf{3}$ ).

\section{Discussion}

Of the 150 isolates collected 130 (86.6\%) were E. faecalis and 20 (13.3\%) were E. faecium. This reflects the preponderance of E. faecalis over E. faecium among the pathogenic enterococcal species. Almost all the studies had E. faecalis as the

Table 2 Sample wise distribution of the species

\begin{tabular}{|l|l|l|l|}
\hline $\begin{array}{l}\text { Source of the } \\
\text { isolates }\end{array}$ & $\begin{array}{l}\text { Enterococcus } \\
\text { faecalis }\end{array}$ & $\begin{array}{l}\text { Enterococcus } \\
\text { faecium }\end{array}$ & Total \\
\hline Exudate & 82 & 13 & 95 \\
\hline Urine & 46 & 6 & 52 \\
\hline Blood & 2 & 1 & 3 \\
\hline Total & 130 & 20 & 150 \\
\hline
\end{tabular}



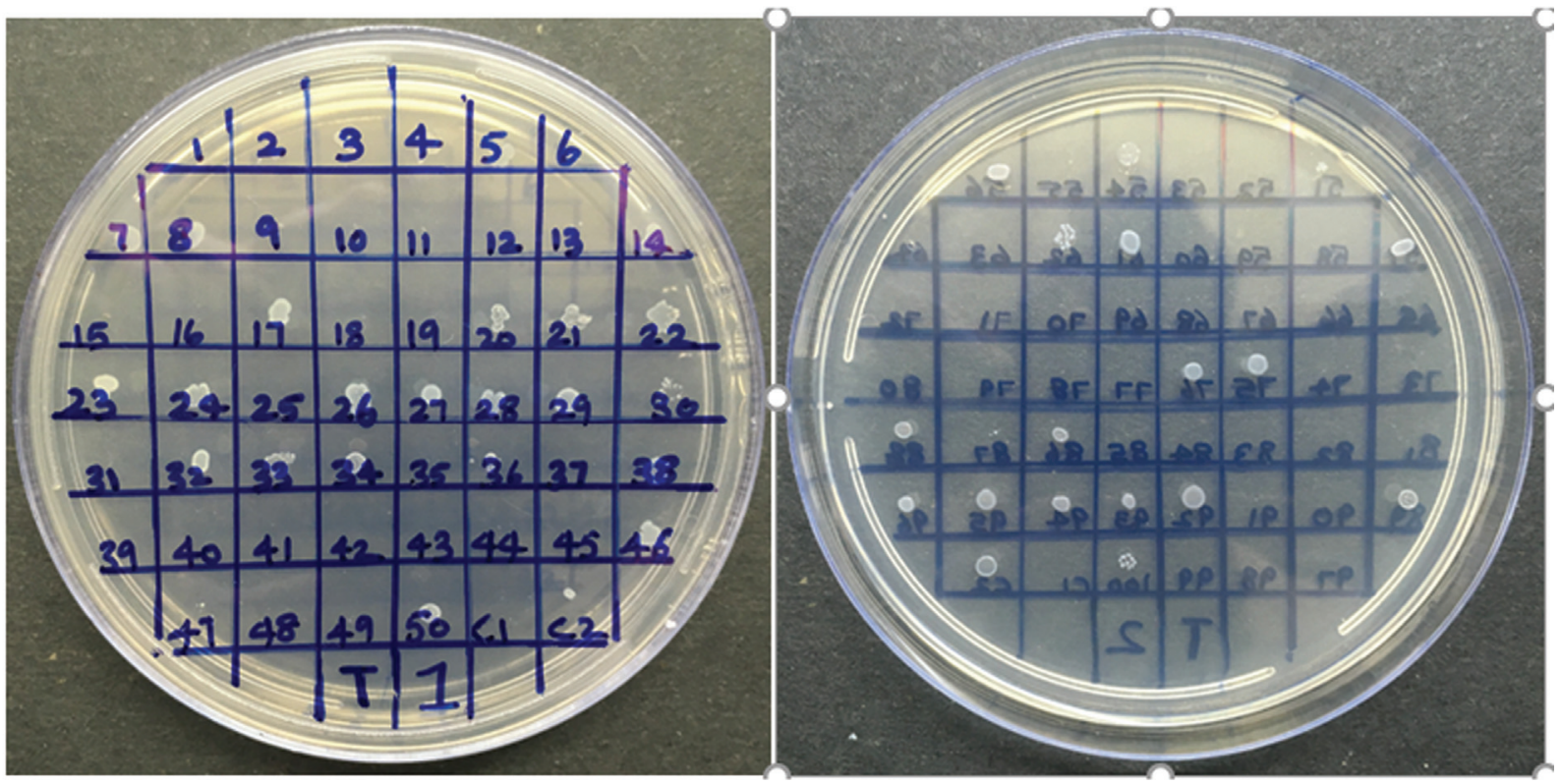

Fig. 2 Image of minimum inhibitory concentration (MIC) testing for high level gentamicin (> $500 \mu \mathrm{g} / \mathrm{mL}$ ); done by the agar dilution method.

predominant isolate except few studies, like a study conducted in Michigan by Vakulenko et $\mathrm{al}^{4}$ in which E. faecium was the predominant species. This is in alignment with various other studies conducted across India where $E$. faecalis has been predominant accounting for 80 to $85 \%$.

Of the 150 isolates, $77(51.3 \%)$ were identified to be resistant to high-level gentamicin phenotypically. Majority of the HLGR enterococci were from urine 47 (61\%), followed by exudates 30 (39\%). There was no HLGR enterococci isolated from blood stream. The speciation revealed that 60 (78\%) were E. faecium and 17 (22\%) were E. faecalis. This is in concordance with the previous study from Chennai by Padmasini et $\mathrm{al}^{2}$ where E. faecium 39 (51.3\%) was found to have higher rates of HLGR than E. faecalis 32 (42\%).

The percentage of HLGR in this study was $51.3 \%$, while a few study had lower incidence of HLGR ranging from 27.7 to $49.2 \%$. Others reported higher incidence of $60 \%$ to $68 \%$.

Out of the 150 study isolates, 77 (51.3\%) were found to be resistant to high-level gentamicin by the agar dilution method. The results of MIC by the agar dilution method and the Kirby-Bauer disc diffusion method were in concordance. No discrepancy was noted, hence the disc diffusion method can be used as a reliable screening test to detect HLGR in enterococci in a clinical laboratory.

Although a spectrum of AME genes are known to be responsible for HLAR status among Enterococcus species, in this study only $\operatorname{aac}\left(6^{\prime}\right)-1 e$ - $a p h\left(2^{\prime \prime}\right)-1 a$ and $\operatorname{aph}\left(3^{\prime}\right)$-llla were encountered among the six genes screened for. Among the study isolates, $55.3 \%(83 / 150)$ isolates had $\operatorname{aac}\left(6^{\prime}\right)-1 e-\operatorname{aph}\left(2^{\prime}\right.$ ')-1a gene and $62.6 \%$ (94/150) isolates had aph(3')-llla gene. Varying distribution of both the genes has been cited in the medical literature: $\operatorname{acc}\left(6^{\prime}\right)-1 e-\operatorname{aph}\left(2^{\prime \prime}\right)-1 a(38.5-80 \%)$; $\operatorname{aph}\left(3^{\prime}\right)$ llla (40-40.4\%). The coexistence of these genes was noted in $44 \%$ (66/150) isolates in the current study, which is twice that of the previous study from Chennai by Padmasini et al, ${ }^{2}$ which had only $20.2 \%$. Other major AME genes like $a p h\left(2^{\prime \prime}\right)-1 b$, aph(2")-1c, $\operatorname{aph}\left(2^{\prime \prime}\right)-1 d$, and $\operatorname{ant}\left(4^{\prime}\right)-1 a$ were not detected in this study. Previous studies from India had also reported similar AME gene profile with only $\operatorname{aac}\left(6^{\prime}\right)-1 e$ - $\operatorname{aph}\left(2^{\prime \prime}\right)-1 a$ and $\operatorname{aph}\left(3^{\prime}\right)$-llla genes being detected. ${ }^{2,10}$ This observation emphasizes the restricted gene distribution and transfer of resistance gene confined to a geographical region.

Studies from abroad, like the study by Diab et al from Egypt, have observed the presence of aminoglycoside-modifying gene aac (6')-Ie-aph (2")-Ia only in 66.7\% of their HLGR isolates and $a p h\left(3^{\prime}\right)$-IIIa gene in $86.5 \%$ of high-level streptomycin resistance isolates. $a p h\left(2^{\prime}\right)-I b$, $a p h\left(2^{\prime}\right)$-Ic, and $a p h\left(2^{\prime}\right)$ Id were not detected. ${ }^{11}$

Moussa et al characterized HLAR for the presence of AME. The bifunctional AME gene aac(6')-Ie-aph(2")-Ia that confers HLR to gentamicin was detected in $40 \%$ of $E$. faecalis and $E$. faecium isolates, whereas 32\% carried aph(3')-IIIa. Other AME

Table 3 Distribution pattern of various AME genes

\begin{tabular}{|c|c|c|c|c|c|c|}
\hline \multirow[t]{2}{*}{ No. of strains with gene(s) } & \multicolumn{6}{|l|}{ Presence of gene } \\
\hline & $\operatorname{aac}\left(6^{\prime}\right)-1 e-a p h\left(2^{\prime \prime}\right)-1 a$ & $a p h\left(2^{\prime \prime}\right)-1 b$ & $\operatorname{aph}\left(2^{\prime \prime}\right)-1 c$ & $\operatorname{aph}\left(2^{\prime \prime}\right)-1 d$ & $a p h\left(3^{\prime \prime}\right)-111 a$ & ant(4')-111a \\
\hline 17 & + & - & - & - & - & - \\
\hline 28 & - & - & - & - & + & - \\
\hline 66 & + & - & - & - & + & - \\
\hline
\end{tabular}

Abbreviation: AME, aminoglycoside- modifying enzyme. 
genes such as $\operatorname{aph}\left(2^{\prime \prime}\right)-I b, \operatorname{aph}\left(2^{\prime \prime}\right)-I c$, and $\operatorname{aph}\left(2^{\prime \prime}\right)$-Id were not detected in their study as well. ${ }^{12}$

Elsewhere in Michigan, Vakulenko et $\mathrm{al}^{4}$ detected the presence of all majorly prevalent AME genes: $\operatorname{aac}\left(6^{\prime}\right)$-Ie-aph (2")-Ia, $\operatorname{aph}\left(2^{\prime \prime}\right)-I b, a p h\left(2^{\prime \prime}\right)-I c, a p h\left(2^{\prime \prime}\right)-I d$, aph(3')-IIIa, and ant (4')-Ia. Of the 93 gentamicin-resistant isolates, all contained either the $\operatorname{aac}\left(6^{\prime}\right)-I e-a p h\left(2^{\prime \prime}\right)-I a, a p h\left(2^{\prime \prime}\right)-I b$, aph(2")-Ic, or aph (2")-Id gene and one isolate carried both aac(6')-Ie-aph(2")-Ia and $\operatorname{aph}\left(2^{\prime \prime}\right)-$-Ic. The $\operatorname{aph}\left(3^{\prime}\right)$-IIIa gene was present in 80 of 113 isolates, and the ant(4')-Ia gene was present in 26 of 113 isolates. Five of the 20 isolates with low-level resistance to gentamicin contained none of the six genes studied.

In the present study, though 77 (51.3\%) of the isolates were phenotypically resistant to gentamicin, 13(8.6\%) did not harbor the majorly prevalent AME genes. It may be proposed that they may harbor genes other than those screened for in this study. In contrast, 47 (31.3\%) harbored the AME genes but phenotypically appeared susceptible to gentamicin. Possibly they were not expressed, and this observation is in concordance with a previous study from Chennai. ${ }^{2}$

\section{Conclusion}

Enterococcus faecalis is more common than E. faecium among clinical isolates of enterococci. For detection of HLGR, the performance of the disc diffusion susceptibility test is similar to MIC determination by agar dilution. Hence the disc diffusion test can be used as a reliable screening test for HLGR in clinical microbiology laboratory. The most common AMEs mediating HLGR are $a a c\left(6^{\prime}\right)-1 e-a p h\left(2^{\prime \prime}\right)-1 a$ and $a p h\left(3^{\prime}\right)-111 a$. This indicates that HLAR genes are widely disseminated among enterococci in our geographical region. This study also emphasizes that the detection of AMEs by PCR is mandatory because strains that appear susceptible by disc diffusion and/or MIC method may harbor one or more AME genes leading to therapeutic failure. And also frequent surveillance studies should be conducted among Enterococcus isolates to document the resistant gene profile.

Conflict of Interest

None.

\section{Reference}

1 García-Solache M, Rice LB. The Enterococcus: a model of adaptability to its environment. Clin Microbiol Rev 2019;32(02): e00058-18

2 Padmasini E, Padmaraj R, Ramesh SS. High level aminoglycoside resistance and distribution of aminoglycoside resistant genes among clinical isolates of Enterococcus species in Chennai, India. ScientificWorldJournal 2014;2014:329157

3 Kobayashi N, Alam M, Nishimoto Y, Urasawa S, Uehara N, Watanabe N. Distribution of aminoglycoside resistance genes in recent clinical isolates of Enterococcus faecalis, Enterococcus faecium and Enterococcus avium. Epidemiol Infect 2001;126(02): 197-204

4 Vakulenko SB, Donabedian SM, Voskresenskiy AM, Zervos MJ, Lerner SA, Chow JW. Multiplex PCR for detection of aminoglycoside resistance genes in enterococci. Antimicrob Agents Chemother 2003;47(04):1423-1426

5 Ozarslan Kurtgoz S, Ozer B, Inci M, Duran N, Yula E. Vancomycin and high-level aminoglycoside resistance in Enterococcus species. Microbiol Res (Pavia) 2016;7:1

6 Carlier C, Courvalin P. Emergence of 4',4"-aminoglycoside nucleotidyltransferase in enterococci. Antimicrob Agents Chemother 1990;34(08):1565-1569

7 Gray GS, Fitch WM. Evolution of antibiotic resistance genes: the DNA sequence of a kanamycin resistance gene from Staphylococcus aureus. Mol Biol Evol 1983;1(01):57-66

8 Matsumura M, Katakura Y, Imanaka T, Aiba S. Enzymatic and nucleotide sequence studies of a kanamycin-inactivating enzyme encoded by a plasmid from thermophilic bacilli in comparison with that encoded by plasmid pUB110. J Bacteriol 1984;160(01): 413-420

9 Trieu-Cuot P, Courvalin P. Nucleotide sequence of the Streptococcus faecalis plasmid gene encoding the 3'5"-aminoglycoside phosphotransferase type III. Gene 1983;23(03):331-341

10 Shete V, Grover N, Kumar M. Analysis of aminoglycoside modifying enzyme genes responsible for high-level aminoglycoside resistance among enterococcal isolates. J Pathogens 2017; 2017:3256952

11 Diab M, Salem D, El-Shenawy A, et al. Detection of high level aminoglycoside resistance genes among clinical isolates of Enterococcus species. Egypt J Med Hum Genet 2019;20:28

12 Moussa AA, Md Nordin AF, Hamat RA, Jasni AS. High level aminoglycoside resistance and distribution of the resistance genes in Enterococcus faecalis and Enterococcus faecium from teaching hospital in Malaysia. Infect Drug Resist 2019; 12:3269-3274 